\title{
Influence of Micronutrient Intake, Sociodemographic, and Behavioral Factors on Periodontal Status of Adults Assisted by a Public Health Care System in Brazil: A Cross-Sectional Multivariate Analysis
}

\author{
Patrícia Daniela Costa ${ }^{1}$, Juliana Cristina Reis Canaan ${ }^{1}$, Paula Midori Castelo ${ }^{2} \mathbb{D}$, Douglas Campideli Fonseca ${ }^{3}$, \\ Stela Márcia Pereira-Dourado ${ }^{1}$ (D), Ramiro Mendonça Murata ${ }^{4}$ (D), Vanessa Pardi ${ }^{4, *(D)}$ and Luciano José Pereira ${ }^{1, *}$ \\ 1 Health Sciences Faculty, Universidade Federal de Lavras (UFLA), 37200-900 Lavras, Minas Gerais, Brazil; \\ patriciadaniela.costa@yahoo.com.br (P.D.C.); reisjuliana@yahoo.com.br (J.C.R.C.); \\ stelapereira@ufla.br (S.M.P.-D.) \\ 2 Department of Pharmaceutical Sciences, Universidade Federal de São Paulo (UNIFESP), \\ 09913-030 Diadema, São Paulo, Brazil; paula.castelo@unifesp.br \\ 3 Dental School, Centro Universitário de Lavras (UNILAVRAS), 37200-000 Lavras, Minas Gerais, Brazil; \\ douglas.perio@gmail.com \\ check for \\ updates \\ Citation: Costa, P.D.; Canaan, J.C.R.; \\ Midori Castelo, P.; Campideli \\ 4 Department of Foundational Sciences, School of Dental Medicine, East Carolina University (ECU), \\ Greenville, NC 27834, USA; muratar16@ecu.edu \\ * Correspondence: pardiv19@ecu.edu (V.P.); lucianojosepereira@ufla.br (L.J.P.); Tel.: +1-252-737-6960 (V.P.); \\ +55-35-3829-5211 (L.J.P.)
}

Fonseca, D.; Márcia Pereira-Dourado,

S.; Mendonça Murata, R.; Pardi, V.;

Pereira, L.J. Influence of

Micronutrient Intake,

Sociodemographic, and Behavioral

Factors on Periodontal Status of

Adults Assisted by a Public Health

Care System in Brazil: A

Cross-Sectional Multivariate Analysis.

Nutrients 2021, 13, 973. https://

doi.org/10.3390/nu13030973

Academic Editors: Ailsa Welch and Siân Robinson

Received: 17 February 2021

Accepted: 16 March 2021

Published: 17 March 2021

Publisher's Note: MDPI stays neutral with regard to jurisdictional claims in published maps and institutional affiliations.

Copyright: (c) 2021 by the authors. Licensee MDPI, Basel, Switzerland This article is an open access article distributed under the terms and conditions of the Creative Commons Attribution (CC BY) license (https:// creativecommons.org/licenses/by/ $4.0 /)$
Abstract: The lack of access to a balanced diet, rich in vitamins and minerals, can predispose people to inflammatory diseases such as obesity, diabetes mellitus, and periodontitis. We aimed to evaluate the relationship between micronutrient intake, sociodemographic behavioral characteristics, and periodontal health in adults assisted by a public health care system. Participants $(n=450)$ answered a food frequency questionnaire and were submitted to anthropometric and oral clinical examinations. Principal component analysis was used to summarize the number of components emerging from 17-micronutrient intake. Subsequently, cluster analysis was employed. The prevalence of at least one periodontal pocket $\geq 4 \mathrm{~mm}$ was $67.4 \%$. Three clusters were identified according to periodontal status. Cluster 1 "poor periodontal status" was characterized by older individuals $(n=202 ; 85 \%$ females) with poor periodontal status, lower education level, mainly smokers with non-transmissible chronic diseases (NTCD), with lower energy, omega-3, fiber, $\mathrm{Zn}, \mathrm{K}, \mathrm{Cu}$, and vitamin $\mathrm{C}$ intake. Cluster 3 "healthy periodontal status" included younger individuals $(n=54)$ with the healthiest periodontal status, a higher education level, without NTCD, and with higher energy, omega-3, fiber, $\mathrm{Zn}$, calcium, retinol, and riboflavin intake. Cluster 2 was labeled as "intermediate periodontal status". Micronutrient ingestion was associated with periodontal status and may be considered in health promotion actions for low-income populations.

Keywords: periodontal diseases; public health; nutritional research; micronutrients

\section{Introduction}

Periodontal diseases represent a set of inflammatory conditions in the supporting tissues of the teeth, initiated by the presence of a dysbiotic biofilm [1,2] in the favor of pathogenic bacteria such as Porphyromonas gingivalis, Prevotella intermedia, Aggregactibacter actinomycetemcomitans, and Fusobacterium nucleatum [3]. Bacterial products initiate a local inflammatory response in the gingival tissue, releasing interleukins, prostaglandins, and other cytokines that activate osteoclasts [4-6]. Such activation leads to the resorption of the alveolar bone with a consequent deepening of the gingival sulcus, generating mobility and in some cases even tooth loss [7]. The high prevalence of periodontitis constitutes an important public health problem [8-10]. When untreated, periodontitis can lead to a loss of 
masticatory function [11], aesthetic damage, and impaired social interaction and quality of life [12].

As the progression of periodontitis depends on the activity of the host's immune system, nutritional factors have been highlighted as sources of interference and modulation. A deficient diet, lacking fruits and vegetables, and therefore poor in micronutrients (such as vitamins and minerals) favors the exacerbation of the periodontal inflammatory response [13]. Micronutrients are essential for maintaining general health, being necessary for the synthesis of a variety of structural biomolecules and also for immune functions [14] The identification of a nutritional profile associated with better periodontal health can generate inexpensive and safe methods for the prevention and treatment of pathological conditions of the periodontium [15] at the population level.

A low-carbohydrate diet, rich in omega-3 fatty acids, vitamins $C$ and $D$, and fiber, can significantly reduce gum and periodontal inflammation [16-22]. However, few studies have been conducted on populations from upper-middle-income countries, where social and nutritional issues are different from the context of developed countries. In addition, Brazil has a universal, free, and public health care system that greatly modifies the context of assessment in relation to previous studies [23,24]. The family health strategy (FHS) is a model of primary health care (PHC) that uses a multidisciplinary approach. The services offered include medical consultations, dental care, preventive exams, and home visits [25-27]. About 65\% of households in Brazil are registered at the FHS, with the majority of this population having a low level of education and low income [27-29]. The FHS represents the gateway to Brazilian public health care. Therefore, understanding the social determinants of the health-disease process in this population allows for a wide range of actions directed to health care, prevention, and promotion [30].

The present study aimed to examine the relationship between micronutrient intake, sociobehavioral factors, chronic diseases, and periodontal status in adults assisted by the public primary health care system. The findings of the present study may guide low-cost and population-based preventive measures for the public health system, considering the characteristics of low-income populations.

\section{Materials and Methods}

\subsection{Study Sample}

The study was carried out in the units of the FHS in the city of Lavras (approximately 110,000 citizens, demographic density 163.26 inhabit $/ \mathrm{km}^{2}$ ), latitude $21^{\circ} 14^{\prime} 43$ south and at a longitude $44^{\circ} 59^{\prime} 59$ west, in the state of Minas Gerais, Brazil during the years of 2019-2020. The last human development index (HDI, 2010) of Lavras is 0.782, which places this municipality in the high range of the HDI (0.700-0.799). We decided to study a population that is served by FHS because this strategy covers the majority of households in Brazil and represents the main input to the Brazilian public health care system. This study initiated on March 2019 and lasted until August 2020. The present research protocol was approved by the Human Research Ethics Committee of the Federal University of Lavras (COEP/UFLA, Minas Gerais, Brazil—Protocol Number: 85767618.1.0000.5148). All procedures were in accordance with the Ministry of Health resolution 466/12 from the Brazilian government. We followed the Strengthening the Reporting of Observational Studies in Epidemiology (STROBE) statement checklist for cross-sectional studies. The research participants read and signed the free and informed consent form (ICF) and all doubts were solved before any procedure was performed.

The participants were selected randomly by means of probabilistic sampling by clusters, proportionally among the 17 different city health units, within people registered with the FHS at the time of the project's start (52,628 individuals). The selection was systematic, based on patient records, in accordance with the inclusion criteria, comprising all micro areas of each health agent in each unit. The inclusion criteria for study participants were: men and women over 18 years of age, who had at least 8 natural teeth, and who agreed to participate voluntarily in the research project. People with mental health disorders, 
under orthodontic treatment, and pregnant women were excluded. The sample calculation was performed using the estimated prevalence of periodontitis [31], with precision of the absolute estimate of 5\% and a significance level of 5\% [32], resulting in a sample of 361 individuals. Due to the possibility of losses and the variability in the number of individuals belonging to each coverage region, this calculation was increased by $20 \%$, totaling the minimum number of 434 individuals. It was then decided to evaluate 450 individuals (Figure 1).

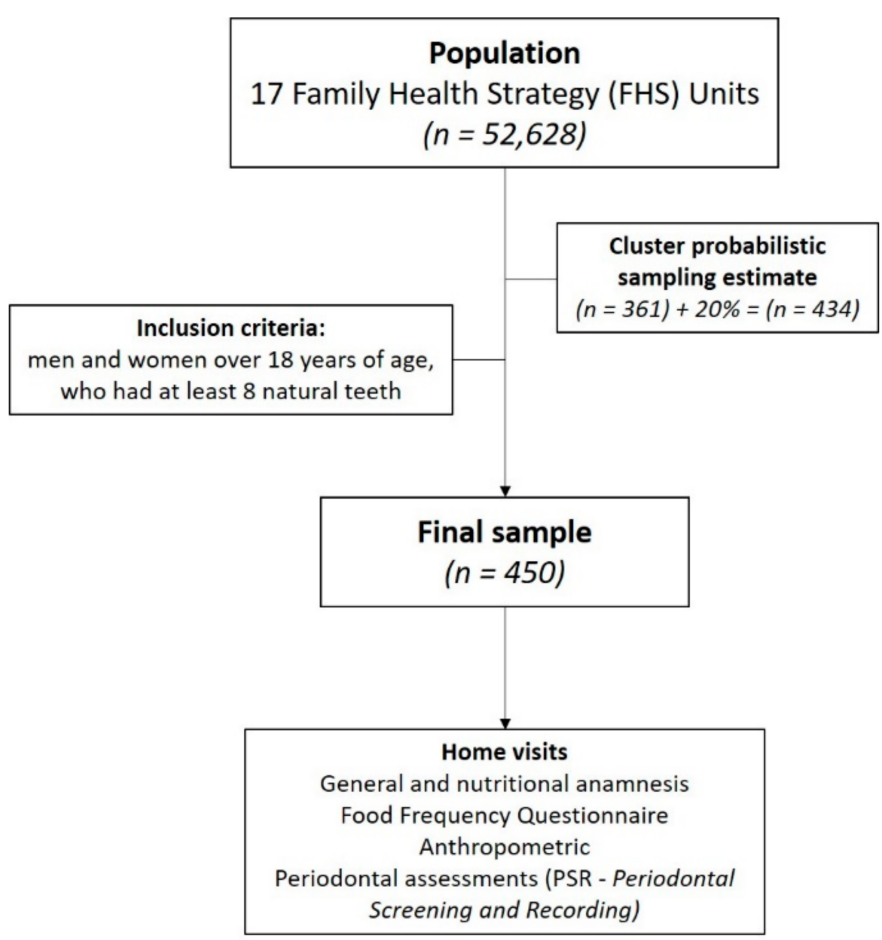

Figure 1. Flowchart of the study design and sample selection.

\subsection{Data Collection}

Data collections related to nutritional variables and the periodontal status of the population were carried out in a cross-sectional design, through home visits. In each visit, general and nutritional interviews were carried out, also applying the food frequency questionnaire [33], followed by anthropometric [34] and periodontal assessments [35]. The same nutritionist professional, a member of the team, collected nutritional data with the aid of an album containing photos of portion sizes (developed to facilitate volunteers to visualize their food portions). The amount and types of food intake reported by each volunteer were screened for the amount of micronutrients such as omega-3 (N-3), omega-6 $(\mathrm{N}-6)$, iron $(\mathrm{Fe})$, copper $(\mathrm{Cu})$, magnesium $(\mathrm{Mg})$, manganese $(\mathrm{Mn})$, phosphorus $(\mathrm{P})$, sodium $(\mathrm{Na})$, potassium $(\mathrm{K})$, zinc $(\mathrm{Zn})$, calcium $(\mathrm{Ca})$, dietary fiber, vitamin $\mathrm{C}$, vitamin $\mathrm{A}$ (retinol), thiamine, riboflavin, pyridoxine, and niacin, as well as macronutrients, carbohydrate, proteins, and lipids.

Anthropometric measurements were performed according to the technical standard of the food and nutrition surveillance system (SISVAN) [34]. The body mass index $\left(\mathrm{BMI}=\right.$ weight $\left.(\mathrm{Kg}) /(\text { height }(\mathrm{m}))^{2}\right)$ was calculated [36]. To assess the waist circumference, data were collected and categorized according to the risk for metabolic complications (men $>94 \mathrm{~cm}$ and women $>80 \mathrm{~cm}$ ) [37].

The periodontal clinical examination was performed on all volunteers by a single examiner, properly trained and calibrated, in the room with best natural lighting. The individual remained seated in a chair and the examiner, wearing proper personal protective equipment, was standing beside the volunteer. A Williams-type periodontal probe with 
gradations of $1,2,3,5,7,8,9$, and $10 \mathrm{~mm}$, and a sterile mouth mirror (Trinity Indústria e Comércio Ltda., São Paulo, Brazil) were used.

Periodontal evaluation was performed using PSR (periodontal screening and recording) $[35,38]$. All teeth were evaluated (with the exception of third molars). The mouth was split into sextants and each of them was classified using an ordinal scale starting from healthy (score 0 ), bleeding on probing (score 1), presence of calculus (score 2), probing depth of 4-5 mm (score 3), and probing depth $\geq 6 \mathrm{~mm}$ (score 4 ). If all teeth of a given sextant were absent (toothless), no observations were recorded for that sextant. We used the worst sextant (highest score) to determine patient's periodontal status.

Variables including sex, age, educational level, smoking habits, family income, and frequency of physical activity, as well as the presence of non-transmissible chronic diseases such as diabetes mellitus, hypertension, and dyslipidemia were obtained through interviews. The educational level was categorized as up to 8 years of study or more. Smoking was classified as non-smoker or smoker. Alcohol consumption was dichotomized at a frequency greater than or equal to twice a week. Family income was dichotomized at up to two or more minimum wages (about US\$ 500).

\subsection{Statistics}

Statistical analysis was performed using SPSS v26.0 software (IBM SPSS Statistics for Windows, v26.0. Armonk, NY, USA: IBM Corp) considering an alpha level of 5\% by an applied statistics spec. Principal component analysis (PCA) was used to estimate the number of components emerging from micronutrients intake (Omega-3, total cholesterol, fiber, calcium, $\mathrm{Mg}, \mathrm{Mn}, \mathrm{P}, \mathrm{Fe}, \mathrm{Na}, \mathrm{K}, \mathrm{Cu}, \mathrm{Zn}$, retinol, thiamine, riboflavin, pyridoxine, niacin, and vitamin C) after Z-score transformation. First, the correlation matrix of the standardized variables was examined, and the number of components to retain was based on eigenvalues, total of explained variance, and scree plot examination. As the variables showed moderate correlations, an oblimin rotation was performed. The overall KaiserMeyer-Olkin (KMO) measure and Bartlett's test of sphericity were examined, which are required for a good principal component analysis.

Furthermore, K-means cluster analysis was performed to identify groups of participants with similar nutritional intake, chronic diseases (diabetes mellitus, hypertension, hypercholesterolemia, hypertriglyceridemia, hypothyroidism, liver steatosis, cardiopathy, cancer history, depression), anthropometric characteristics and, periodontal status. The analysis included the following variables: age, sex, BMI, physical activity, chronic diseases, smoking, alcohol consumption, income, formal education, dental treatment in the last year, and component loadings generated from PCA summarizing micronutrients data. The final number of clusters was based on the interpretability and reliability of the cluster solution; the silhouette coefficient and the differences between clusters assessed by One-way ANOVA testing was used for clustering validation.

\section{Results}

The mean age of participants was approximately 50 years old. The prevalence of at least one periodontal pocket $\geq 4 \mathrm{~mm}$ was $67.4 \%$ (PSR scores 3 and 4 ). In general, the sample comprised of overweight (mean BMI $=28.5)$, sedentary $(66.25 \%)$, and non-smoking (75.9\%) participants. The prevalence of diabetes mellitus was $28.2 \%$, whereas high blood pressure affected $50 \%$ of the individuals. Alcohol consumption was more frequent among men $(20 \%)$. Around $40 \%$ of the sample had undergone dental treatment within the last year, and $65.75 \%$ of them had a low family income (Table 1$)$. Protein ( $46 \mathrm{~g} /$ day for women and $56 \mathrm{~g}$ /day for men) intake was above recommended levels in accordance with dietary reference [39]. Fiber intake was below the recommended level for adults ( $25 \mathrm{~g} / \mathrm{day}$ for women and $38 \mathrm{~g} /$ day for men), as was as omega-3 (1.1 mg/day and $1.6 \mathrm{mg} /$ day for women and men) and zinc ( $8 \mathrm{mg} /$ day for women and $11 \mathrm{mg} /$ day for men) (Table 1$)$. 
Table 1. Sample distribution in accordance with socio-demographic and nutritional profile $(n=450)$.

\begin{tabular}{|c|c|c|c|}
\hline Continuous Variables & $\begin{array}{c}\text { Female } \\
\text { Mean }( \pm \text { SD) }\end{array}$ & $\begin{array}{c}\text { Male } \\
\text { Mean }( \pm \text { SD) }\end{array}$ & $\begin{array}{c}\text { Range } \\
\text { (Female/Male) }\end{array}$ \\
\hline Age (years) & $50(12.5)$ & $51.9(13.6)$ & 19-79/18-78 \\
\hline BMI & $29.5(6.1)$ & $27.6(5.1)$ & $17-54.3 / 17.2-42.3$ \\
\hline Energy intake (Kcal/day) & 1495 (411.3) & $1756(526.3)$ & $620-3214 / 772-3070$ \\
\hline Carbohydrates (g/day) & $219.26(64.7)$ & $248.6(75)$ & $89.6-475.8 / 108.5-437.9$ \\
\hline Lipids (g/day) & $41.6(15.04)$ & $48.5(18)$ & 12.5-92.1/10.6-102.1 \\
\hline Protein (g/day) & $60.76(18.5)$ & $73.8(25.7)$ & 21.1-123.6/21.1-174 \\
\hline Zinc (mg/day) & $7.41(3.00)$ & $9.75(5.52)$ & $1.9-19.6 / 2.4-36.5$ \\
\hline Fiber (g/day) & $21(7.90)$ & $25(9.47)$ & $3.4-46.8 / 7.6-44.8$ \\
\hline Omega-3 (mg/day) & $0.57(0.21)$ & $0.69(0.24)$ & $0.12-1.35 / 0.24-1.5$ \\
\hline Cholesterol (mg/day) & $229.5(115.2)$ & $278.0(169.9)$ & $15.5-972.1 / 72,6-1511.8$ \\
\hline Calcium (mg/day) & $418.3(236.7)$ & $445.83(268.29)$ & $52.2-1341.8 / 136.0-1295.5$ \\
\hline Magnesium (mg/day) & $195.79(58.74)$ & $227.33(76.83)$ & $66.0-402.7 / 77.30-451.9$ \\
\hline Manganese (mg/day) & $1.93(0.60)$ & $2.22(0.76)$ & $0.7-3.9 / 1.0-4.3$ \\
\hline Phosphorus (mg/day) & $892.69(317.8)$ & $1056.29(395.5)$ & 254.3-2142.8/367.2-2580.1 \\
\hline Iron (mg/day) & $5.76(1.89)$ & $6.83(2.22)$ & $2.0-14.0 / 2.7-14.8$ \\
\hline Sodium (mg/day) & $1165.21(473.16)$ & $1334.16(487.9)$ & $287.3-3634.0 / 249.6-2902.9$ \\
\hline Potassium (mg/day) & $2193.11(657.48)$ & $2407.46(787.8)$ & 780.7-4686.0/850.8-4956.5 \\
\hline Copper (mg/day) & $0.84(0.44)$ & $0.86(0.3)$ & $0.2-3.1 / 0.3-1.6$ \\
\hline Retinol (mg/day) & $170.30(117.15)$ & $182.02(121.92)$ & $4.2-779.8 / 19.70-654.80$ \\
\hline Thiamine (mg/day) & $0.82(0.29)$ & $0.92(0.35)$ & $0.2-2.0 / 0.3-2.4$ \\
\hline Riboflavin (mg/day) & $1.01(0.52)$ & $1.06(0.34)$ & $0.1-3.9 / 0.3-2.8$ \\
\hline Pyridoxine (mg/day) & $0.54(0.31)$ & $0.70(0.50)$ & $0.1-2.7 / 0-2.5$ \\
\hline Niacin (mg/day) & $12.56(5.8)$ & $16.89(10.15)$ & $1.6-45.1 / 2.40-58.90$ \\
\hline Vitamin C (mg/day) & $136.19(101.63)$ & $123.06(101.46)$ & $4.0-573.2 / 12.50-561.80$ \\
\hline Dichotomous variables & Female $n(\%)$ & Male $n(\%)$ & \\
\hline $\begin{array}{c}\text { Presence of at least one } \\
\text { periodontal pocket } \geq 4 \mathrm{~mm} \text { ) }\end{array}$ & $234(65.9 \%)$ & $70(73.7 \%)$ & \\
\hline $\begin{array}{l}\text { Physical activity practice ( } \geq \\
\qquad 3 \times / \text { week })\end{array}$ & $113(32.8 \%)$ & $33(34.7 \%)$ & \\
\hline Diabetes mellitus (yes) & $100(28 \%)$ & $27(28.4 \%)$ & \\
\hline Hypertension (yes) & $180(50.7 \%)$ & $47(49.5 \%)$ & \\
\hline Hypercholesterolemia (yes) & $90(25.4 \%)$ & $16(16.8 \%)$ & \\
\hline Hypertriglyceridemia (yes) & $7(2 \%)$ & 0 & \\
\hline Hypothyroidism (yes) & $26(7.3 \%)$ & $2(2.1 \%)$ & \\
\hline Liver steatosis (yes) & $7(2 \%)$ & $1(1.1 \%)$ & \\
\hline Cardiopathy (yes) & $22(6.2 \%)$ & $3(3.2 \%)$ & \\
\hline Cancer history (yes) & $8(2.3 \%)$ & $2(2.1 \%)$ & \\
\hline Depression (yes) & $24(6.8 \%)$ & $3(3.2 \%)$ & \\
\hline Smoking (yes) & $74(20.8 \%)$ & $26(27.4 \%)$ & \\
\hline Family income ( $>2$ wages) & $120(33.8 \%)$ & $33(34.7 \%)$ & \\
\hline Educational level ( $>8$ years) & $194(54.6 \%)$ & $50(52.6 \%)$ & \\
\hline Dental treatment last year & $123(34.6 \%)$ & $43(45.3 \%)$ & \\
\hline $\begin{array}{l}\text { Alcohol consumption } \\
(>2 \times / \text { week })\end{array}$ & $29(8.2 \%)$ & $19(20 \%)$ & \\
\hline
\end{tabular}

SD: Standard Deviation.

A principal component analysis (PCA) with oblimin rotation was run to identify micronutrient dietary patterns within the study population. The suitability of PCA was assessed prior to analysis; the overall Kaiser-Meyer-Olkin (KMO) measure was 0.813, considered to be "meritorious" according to Kaiser (1974). Bartlett's test of sphericity was statistically significant $(p<0.0001)$, indicating that the data was likely factorizable.

After oblimin rotation of the factors, PCA revealed three components that explained $74 \%$ of the total variance, as confirmed by visual inspection of the scree plot below (Figure 2A) that was used to identify the number of factors to be retained. As such, three components met the interpretability criterion and were retained, as observed in Table 2. 


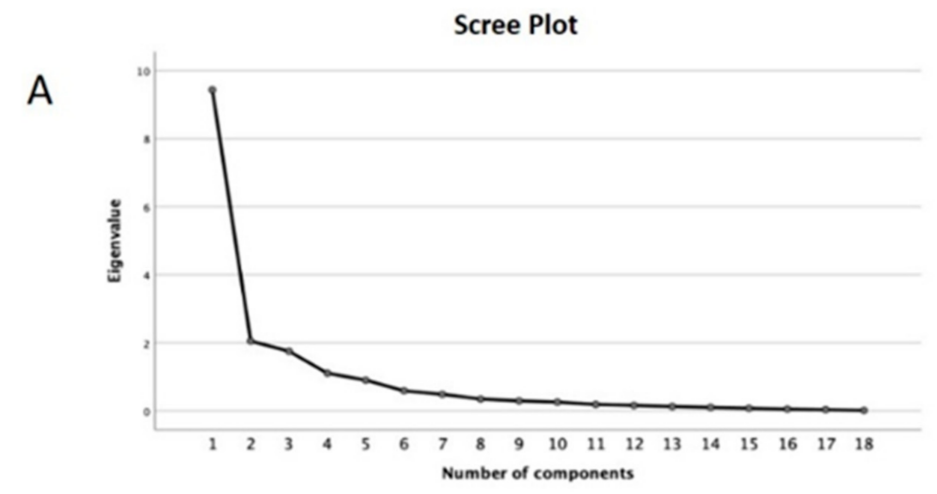

B

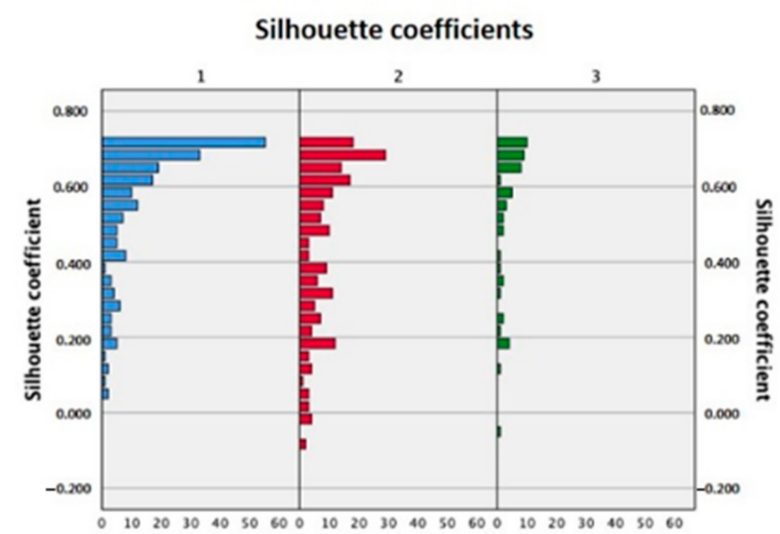

Figure 2. (A) Scree plot with the inflection point at component 3 used to determine the number of components to be retained. (B) Silhouette plot used to examine internal validity of the cluster solution. The $\mathrm{X}$-axis shows the number of cases for each silhouette coefficient shown in the Y-axis.

Table 2. Component loadings of micronutrient intake patterns obtained by principal component analysis with oblimin rotation.

\begin{tabular}{cccc}
\hline Z Scores & \multicolumn{3}{c}{ Component } \\
\cline { 2 - 4 } & $\mathbf{1}$ & $\mathbf{2}$ & $\mathbf{3}$ \\
\hline Zscore (Omega-3) & 0.869 & & 0.372 \\
Zscore (total & 0.701 & & 0.525 \\
cholesterol) & 0.819 & -0.588 & \\
Zscore (fiber) & 0.400 & -0.402 & 0.901 \\
Zscore (calcium) & 0.778 & -0.699 & 0.456 \\
Zscore (Magnesium) & 0.736 & -0.660 & \\
Zscore (Manganese) & 0.757 & -0.334 & 0.849 \\
Zscore (Phosphorus) & 0.938 & -0.435 & 0.396 \\
Zscore (Iron) & 0.590 & -0.723 & 0.514 \\
Zscore (Sodium) & 0.684 & -0.764 & 0.369 \\
Zscore (Potassium) & 0.438 & & 0.522 \\
Zscore (Copper) & 0.865 & & 0.915 \\
Zscore (Zinc) & 0.372 & -0.311 & 0.528 \\
Zscore (Retinol) & 0.604 & & 0.848 \\
Zscore (Thiamine) & 0.320 & & 0.362 \\
Zscore (Riboflavin) & & & \\
Zscore (Piridoxine) & 0.465 & -0.811 & \\
Zscore (Niacin) & &
\end{tabular}

Coefficients less than 0.3 are omitted.

For interpretation purposes, by examining Table 2 it can be assumed that for component 1 , the higher the component, the higher the scores of $\mathrm{N}-3$, cholesterol, fiber, $\mathrm{Mg}, \mathrm{Mn} \mathrm{P}$, 
$\mathrm{Fe}, \mathrm{K}$, and $\mathrm{Zn}$ intake; for component 2, the higher the component, the lower the fiber, $\mathrm{Mg}$, $\mathrm{Mn}, \mathrm{K}, \mathrm{Cu}$, and vitamin $\mathrm{C}$ intake (as the coefficient loadings of component 2 are negative). Finally, for component 3 , the higher the component, the higher the calcium, P, retinol, and riboflavin intake.

Furthermore, K-means cluster analysis included the variables: age, sex, BMI, physical activity, chronic diseases, smoking, alcohol consumption, income, schooling, dental treatment in the last year, and the three component loadings generated from PCA. Analysis identified three reliable and meaningful clusters (Table 3), with an average silhouette width of 0.53 (Figure 2B). The plot indicates that there is a good structure to the clusters, with most observations seeming to belong to the cluster that they were in.

Table 3. Final cluster centers (means) of the social health-related variables (important differences which identify the clusters are shown in a dark gray color).

\begin{tabular}{|c|c|c|c|c|c|}
\hline Variables & $\begin{array}{c}\text { Cluster } 1 \\
\text { "Poor Periodontal } \\
\text { Status" }\end{array}$ & $\begin{array}{c}\text { Cluster } 2 \\
\text { "Intermediate } \\
\text { Periodontal Status" }\end{array}$ & $\begin{array}{c}\text { Cluster } 3 \\
\text { "Healthy Periodontal } \\
\text { Status" }\end{array}$ & F Test & $p$-Value \\
\hline Number of cases & 202 & 194 & 54 & & \\
\hline Periodontal disease severity & 1.06 & 0.94 & 0.74 & 3.831 & 0.022 \\
\hline Age & 54.67 & 48.17 & 43.04 & 25.654 & $<0.001$ \\
\hline Sex & 0.15 & 0.23 & 0.35 & 5.579 & 0.004 \\
\hline BMI & 29.64 & 28.75 & 28.41 & 1.419 & 0.243 \\
\hline Energy intake & 1172.15 & 1706.59 & 2440.00 & 899.059 & $<0.001$ \\
\hline $\begin{array}{c}\text { Micronutrient } \\
\text { intake-component } 1\end{array}$ & -0.71 & 0.33 & 1.51 & 240.647 & $<0.001$ \\
\hline $\begin{array}{c}\text { Micronutrient } \\
\text { intake-component } 2\end{array}$ & 0.31 & -0.15 & -0.62 & 22.771 & $<0.001$ \\
\hline $\begin{array}{c}\text { Micronutrient } \\
\text { intake-component } 3\end{array}$ & -0.44 & 0.17 & 1.08 & 64.526 & $<0.001$ \\
\hline Physical activity & 0.34 & 0.33 & 0.31 & 0.132 & 0.876 \\
\hline Diabetes mellitus & 0.34 & 0.24 & 0.24 & 2.632 & 0.073 \\
\hline Hypertension & 0.55 & 0.50 & 0.35 & 3.576 & 0.029 \\
\hline Hypercholesterolemia & 0.30 & 0.20 & 0.13 & 5.085 & 0.007 \\
\hline Hypertriglyceridemia & 0.02 & 0.02 & 0.00 & 0.543 & 0.581 \\
\hline Hypothyroidism & 0.07 & 0.07 & 0.02 & 1.007 & 0.366 \\
\hline Liver steatosis & 0.03 & 0.00 & 0.02 & 3.433 & 0.033 \\
\hline Cardiopathy & 0.05 & 0.07 & 0.04 & 0.487 & 0.615 \\
\hline Cancer history & 0.03 & 0.02 & 0.00 & 0.879 & 0.416 \\
\hline Renal disease & 0.00 & 0.01 & 0.00 & 0.137 & 0.872 \\
\hline Vascular disease & 0.00 & 0.01 & 0.00 & 0.659 & 0.518 \\
\hline Depression & 0.08 & 0.09 & 0.02 & 0.502 & 0.606 \\
\hline Smoking & 0.28 & 0.19 & 0.13 & 4.194 & 0.016 \\
\hline Family income & 0.34 & 0.38 & 0.27 & 1.071 & 0.344 \\
\hline Educational level & 0.45 & 0.60 & 0.70 & 7.387 & 0.001 \\
\hline Dental treatment last year & 0.36 & 0.37 & 0.39 & 0.077 & 0.926 \\
\hline Alcohol consumption & 0.07 & 0.11 & 0.20 & 3.829 & 0.022 \\
\hline
\end{tabular}

BMI, body mass index. "Female sex" and "Yes" answers were set as $=1$.

Clusters varied significantly according to periodontal status, age, sex, energy, micronutrient intake, smoking, alcohol consumption, educational level, and chronic diseases: hypertension, hypercholesterolemia, and liver steatosis. Graphical Abstract shows the taxonomy description of the three clusters: cluster 1 (labeled "poor periodontal status", $n=202$ ) was characterized by older participants with a higher frequency of chronic diseases and smoking habits, lower energy intake, lower educational level, and being $85 \%$ females. This cluster also showed a higher mean for component 2, being characterized by the lower intake of fiber, $\mathrm{K}, \mathrm{Cu}$, and vitamin $\mathrm{C}$ (indicating a low consumption of micronutrients of this component, since coefficient loadings are negative, see Table 2); besides, the cluster showed a lower mean for component 1, reinforcing the lower N-3, fiber, and $\mathrm{Zn}$ intake. 
Cluster 3 (labeled "healthy periodontal status", $n=54$ ) was characterized by younger participants with a lower frequency of periodontal disease, a proportionally lower frequency of females (65\%), higher energy intake, lower frequency of chronic diseases, higher alcohol consumption, higher educational level, and higher means for components 1 and 3 , being characterized by higher N-3, fiber, $\mathrm{Zn}$, calcium, retinol, and riboflavin consumption. Finally, cluster 2 (labeled "intermediate periodontal status", $n=194$ ) was the contrast, being characterized by the low frequency of liver steatosis and moderate periodontal disease.

\section{Discussion}

The results of the present study highlighted the association between micronutrient intake, mainly of zinc, fibers, and omega-3, and periodontal status. Higher consumption of these micronutrients, together with higher energy intake, higher education level, and lower frequency of NTCD, was associated with better periodontal status. On the other hand, the lower energy intake and low consumption of omega-3, fibers, zinc, lower education level, smoking habits, and the presence of NTCD were associated with worse periodontal status. Other micronutrients such as iron, calcium, retinol, and riboflavin were also consumed more by individuals of the "healthy periodontal status" cluster, while those with the worst periodontal status showed a lower consumption of vitamin C, copper, potassium, and magnesium.

Regarding the consumption of zinc, our results corroborate a previous study in which serum levels of this metal were significantly reduced in patients with periodontitis compared to healthy controls [14]. Zinc, like copper and magnesium, plays an important role in the immune response, as well as in preventing oxidative stress. It helps to modulate the release of cytokines, induces the proliferation of CD 8+ T cells (cytotoxic T lymphocytes), assists in maintaining mucosal integrity, and plays an important role in the growth and differentiation of immune cells, as well as in the activation of T lymphocytes and Th1 response (cell-mediated immunity) [40]. The deficiency of this micronutrient impairs the function of neutrophils and macrophages, favors oxidative processes, and reduces the regenerative capacity [41]. Zinc is a cofactor in more than 300 enzymes and transcription factors, acting mainly as a structural stabilizer [42-44]. Zinc is essential in the repair of injuries, bone mineralization, blood clotting, and many other homeostatic processes linked in some way to periodontal health [45]. The minimum daily consumption recommendation is told to be $8 \mathrm{mg} /$ day for women and $11 \mathrm{mg} /$ day for men [39], but some authors indicate even higher values of $15 \mathrm{mg} /$ day [46] (a much higher value in comparison to the average intake found in the present sample). Finally, zinc is involved in phosphorylation of insulin receptors [47], and its deficiency leads to hyperglycemia and potentially to type 2 diabetes mellitus due to insulin resistance [48]. In a bidirectional way, diabetes can also alter zinc homeostasis [49] due to hyperzincuria and reduced intestinal zinc absorption [48,50]. This fact was observed in our study in which individuals with a worse periodontal status had a higher frequency of chronic diseases, such as diabetes.

Animal studies have shown that an increased intake of dietary fiber can reduce the progression of periodontal disease [51-54]. In humans, a study involving 6052 adults also reported that low dietary fiber consumption was associated with worse periodontal status [55]. The probable mechanism arises from the fact that fibers form a gelatinous layer in the intestine that acts as a barrier, making it difficult for pathogens to penetrate. Additionally, the fermentation of fibers in the intestine alters the microbial profile and increases the generation of short-chain fatty acids (SCFA) that stimulate the production of immunoglobulins A (IgA), improving the systemic immune response [56]. Thus, fiber modulates the expression of inflammatory mediators, such as cyclooxygenase-2 (COX-2), and interleukins (IL-1- $\alpha$, IL-18), reduces the expression receptor activator of the nuclear factor $\kappa B$ ligand (RANK-L), and increases the release of osteoprotegerin (OPG), avoiding alveolar bone loss [17,52]. The physical-chemical characteristics of the fibers differ due to their source and, therefore, promote different local and systemic effects on the human organism. Differences in water retention capacity, viscosity, fermentation, and adsorption, 
among others, are responsible for metabolic implications (systemic effects), as well as in the gastrointestinal tract (local effects), which are dependent on the type and amount of food consumed [57].

The health benefits of consuming omega- 3 are widely known, with great evidence of an immunomodulatory effect in inflammatory status [58]. A systematic review by our group investigated the relationship between plasma concentrations of eicosapentaenoic acid (EPA), docosahexaenoic acid (DHA), and/or arachidonic acid (AA) and periodontal disease. Individuals with higher blood levels of omega-3 from a diet rich in these fatty acids had better periodontal status [59]. When the n3/n6 ratio is increased by the intake of omega-3 fatty acids (DHA and/or EPA), an increase in the production of endogenous anti-inflammatory lipid mediators occurs, contributing to tissue repair. Among the pro-resolution mediators produced, resolvin E1 (RvE1) is an antagonist of eicosanoid leukotriene B4 (LTB4) [60] that inhibits receptors on neutrophils, monocytes, and lymphocytes, reducing the transcription of nuclear factor $\kappa \mathrm{B}(\mathrm{NF} \kappa \mathrm{B})$ and the release of tumor necrosis factor $\alpha$ (TNF- $\alpha)$ [61]. RvE1 is generated locally in response to inflammation, improving the resolution phase of inflammation, decreasing neutrophil chemotaxis, and improving the clearance of apoptotic neutrophils, directed by macrophages. It was found that RvE1 is effective in preventing and restoring bone loss in periodontitis [62,63]. Additionally, polyunsaturated fatty acids (PUFAs), such as omega-3, exert osteoprotective functions (promoting the differentiation and activation of osteoblasts), while inhibiting osteoclast activities [64]. Indeed, a very recent study reported that adjunctive omega-3 and low-dose aspirin provided clinical and immunological benefits to the treatment of periodontitis in patients with type 2 diabetes after periodontal debridement [65]. Thus, an inadequate pro-resolving response from the host may constitute a mechanism that explains the worse periodontal status in individuals with omega-3 deficiency [63].

The results of the present study also showed the participation of other nutrients, such as vitamin $C$ (ascorbic acid), calcium, $K$, retinol and riboflavin. Vitamin $C$ is necessary for collagen synthesis and also acts as an antioxidant [66]. This activity gives vitamin $\mathrm{C}$ a fundamental role in maintaining the integrity of connective tissues, including the periodontium [20-22]. Low calcium intake increases the risk of bone loss associated with periodontal disease $[67,68]$, while low potassium intake, mainly accompanied by low fiber intake, increases blood pressure and periodontal inflammation [69]. Vitamin A plays an important role in maintaining the structural and functional integrity of mucosal cells and is necessary for the proper functioning of $\mathrm{T}$ and $\mathrm{B}$ lymphocytes and, therefore, for generating an immune response [40].

In the present study, in addition to nutritional factors, socio-behavioral factors were also associated with the periodontal status, such as age, sex, smoking, alcohol consumption, educational level, and the presence of NTCD. These results corroborate an American study in which the prevalence of periodontitis was increased due to lower levels of education, advanced age, and smoking [8]. With advancing age, essential constituents of food, such as vitamins and minerals, are absorbed less efficiently, and their production in the body decreases, thus increasing the risk of inflammatory load [19]. Still, the cells and molecules of the innate and adaptive immune response are negatively affected, including in the oral cavity, favoring periodontitis [70].

Inflammatory diseases, such as obesity, type 2 diabetes mellitus, and periodontitis induce the production of pro-inflammatory cytokines, such as Tumor Necrosis Factor alpha (TNF- $\alpha$ ), IL-1, and IL-6, influencing the involvement and progression of each other [71]. Similarly, serum levels of total cholesterol, low density lipoprotein cholesterol (LDL-cholesterol), and triglycerides increase in the presence of periodontal disease, while periodontitis can also be a risk factor for hyperlipidemia. These findings indicate a bidirectional relationship, leading to the vicious cycle of events observed in these individuals [72].

A remarkable factor observed in our results was that $85 \%$ of the individuals with the worst periodontal status were women. Because this cluster was made up of individuals around 50 years of age, it is suggested that this result is influenced by menopause. Peri- 
odontal tissues are sensitive to hormonal changes that occur just before menopause that reduce the body's ability to fight minor infections or maintain a balance between beneficial bacteria and pathogens in the oral environment [73]. Additionally, estrogen deficiency is associated with osteoporosis, with resulting bone loss and a predisposition to inflammatory processes [74,75].

Smoking is also known to be an important risk factor for the development of numerous systemic diseases, as well as periodontitis [76]. Smokers in various age categories exhibit significantly higher levels of antibodies to oral pathogens compared to non-smokers [77]. Smoking increases oxidative stress in periodontal tissues, inhibits defenses against biofilm bacteria, and leads to vascular constriction and slow tissue healing [78-80]. Smoking cessation and the consumption of antioxidant-rich foods or supplements during periodontal treatment favor tissue repair and infection control [78].

In addition to smoking, the periodontal status can be affected even more intensely by the interaction of smoking and alcohol consumption [81]. However, alcohol consumption patterns vary throughout life. Initial increases in volume during adolescence are followed by a more stable period during middle age, before the decrease in volume in older age [82]. This fact justifies the greater alcohol consumption found in the group with the best periodontal status in the present study, as it was characterized by younger individuals. Moderate alcohol intake has been reported to even provide health benefits (cardio and neuroprotection) [83]. However, excessive consumption impairs the function of T cells and neutrophils, increasing the likelihood of infection [84] and the risk of periodontitis in a dose dependent manner [85].

Finally, the present study was conducted in units of the FHS, which represents a public health program that is free and designed to be accessible to the entire population. Unfortunately, coverage is low, but the most vulnerable populations are the priority. Rural and remote areas still lack assistance. In the city where the survey was conducted, the program's coverage rate is $56.52 \%$ (below the Brazilian average of $65.36 \%$ ). However, in relation to total basic health care, the rate in the municipality is $88.78 \%$, while for the whole country it is $76.50 \%$ [86].

The system is comprised of the registration of citizens (carried out by community agents) near the health units. These units have a family physician, a nurse, one nurseassistant, community agents, and a dentist with one oral health assistant. An additional team composed of a nutritionist, a physiotherapist, a psychologist, and a physical education professional also support these units [87] (although some cities do not have this additional team). Approximately $50 \%$ of users live in a situation of socio-economic vulnerability [88], which was reflected in the nutritional and periodontal data. The cost of food is one of the most important determinants of food choices, and family budget constraints are barriers to the adoption of healthy choices in populations with low socioeconomic status $[89,90]$. Family income was not associated with periodontal status in our study because the sample comprised FHS users with similar incomes (70\% had an income below two minimum wages).

Since a significant portion of this population, especially older individuals, frequently visit family health units for consultations [91], our findings indicate educational and preventive issues that might be addressed, greatly impacting the quality of life of this population. Oral health problems are directly related to socioeconomic factors, as observed in the present study. The inclusion of a dentist in the health unit seeks to modify the traditional healing-restorative philosophy in the context of primary care services. In this sense, multi-professional interactions with nutritionists, doctors, nurses, and community agents are essential for offering actual prevention and treatment measures to patients' needs. Investing in the prevention of oral health problems, seeking low-cost measures, and employing individual and collective measures, besides gathering epidemiological knowledge, are fundamental in this context [24,92,93].

The present study has some limitations due to its cross-sectional design and population delimitation, preventing causal relationships and reducing external validity, respectively. 
However, cluster analysis deals with multiple variables at the same time, helping investigators to discover distinct groups in order to develop targeted programs or interventions. When designing nutritional interventions, it is crucial to know the characteristics of the intended population. In this sense, our results are particularly useful for the low-income population served by the public health system to improve dental and nutritional advice. The present results may contribute to community health promotion actions by means of encouraging nutritional campaigns and nutritional advice for specific groups of patients [30]. The identification of a nutritional profile associated with better periodontal health can be an inexpensive and safe method for the prevention and treatment not only of periodontal disease [15] in vulnerable populations assisted by the FHS, but also of other non-transmissible chronic diseases.

In summary, the results of the present study corroborate the concept that an optimized diet for oral health in low-income populations should be mainly rich in omega-3 fatty acids, fiber [16], and zinc [45]. We found that cluster 1 (poor periodontal status) participants showed lower omega-3, fiber, and Zn intakes, whereas cluster 3 (healthy periodontal status) participants showed higher omega-3, fiber, and Zn intakes. Thus, zinc, fiber, and omega-3 were the only nutrients with opposite behaviors in relation to periodontal status. This result indicates the importance of these three nutrients in order to differentiate between the two opposite clusters, 1 and 3 . The relationship between nutrition and periodontal status is of paramount importance, since the loss of dental elements due to periodontitis can negatively affect the patient's nutritional status and vice-versa, leading to the selection of soft, easy to chew, low-nutrient foods, especially in the elderly [13].

\section{Conclusions}

Diet can significantly affect periodontal status, and nutritional deficiencies are very important factors in countries with upper middle-income economies. Brazil has a public health system that greatly modifies the context of oral assistance in relation to other countries. This study highlights the influence of nutritional and sociodemographic behavioral factors on periodontal status, which may guide population-based measures for low-income populations.

Author Contributions: L.J.P., V.P. and R.M.M.: article conception and funding; P.D.C., J.C.R.C., D.C.F.: periodontal and nutritional examinations; P.M.C.: statistical analysis; P.D.C., L.J.P., S.M.P.-D.: manuscript writing; P.D.C., J.C.R.C., D.C.F., P.M.C., L.J.P. All authors have read and agreed to the published version of the manuscript.

Funding: This study was supported by the National Council for Scientific and Technological Development (Conselho Nacional de Desenvolvimento Científico and Tecnológico-CNPq), the Research and Support Foundation of the State of Minas Gerais (Fundação de Amparo and Pesquisa do Estado de Minas Gerais-FAPEMIG) and the Coordination for the Improvement of Higher Education Personnel (Coordenação de Aperfeiçoamento de Nível Superior-CAPES).

Institutional Review Board Statement: The study was conducted according to the guidelines of the Declaration of Helsinki, and the research protocol was approved by the Human Research Ethics Committee of the Federal University of Lavras (COEP/UFLA, MG, Brazil_CAAE: 85767618.1.0000.5148).

Informed Consent Statement: Informed consent was obtained from all subjects involved in the study.

Data Availability Statement: Data will be available upon request.

Acknowledgments: The authors acknowledge the City Major, the Health System Coordinator and all Family Health Strategy professionals for all support during data collection.

Conflicts of Interest: The authors declare no conflict of interest. 


\section{References}

1. Caton, J.G.; Armitage, G.; Berglundh, T.; Chapple, I.L.; Jepsen, S.; Kornman, K.S.; Mealey, B.L.; Papapanou, P.N.; Sanz, M.; Tonetti, M.S. A new classification scheme for periodontal and peri-implant diseases and conditions-Introduction and key changes from the 1999 classification. J. Clin. Periodontol. 2018, 45, S1-S8. [CrossRef]

2. Tonetti, M.S.; Greenwell, H.; Kornman, K.S. Staging and grading of periodontitis: Framework and proposal of a new classification and case definition. J. Clin. Periodontol. 2018, 45, S149-S161. [CrossRef]

3. Lindhe, J.; Ranney, R.; Lamster, I.; Charles, A.; Chung, C.-P.; Flemmig, T.; Kinane, D.; Listgarten, M.; Löe, H.; Schoor, R.; et al. Consensus Report: Chronic Periodontitis. Ann. Periodontol. 1999, 4, 38. [CrossRef]

4. Kinane, D.F.; Lappin, D.F. Clinical, pathological and immunological aspects of periodontal disease. Acta Odontol. Scand. 2001, 59, 154-160. [CrossRef] [PubMed]

5. Rettori, E.; De Laurentiis, A.; Zubilete, M.Z.; Rettori, V.; Elverdin, J.C. Anti-Inflammatory Effect of the Endocannabinoid Anandamide in Experimental Periodontitis and Stress in the Rat. Neuroimmunomodulation 2012, 19, 293-303. [CrossRef] [PubMed]

6. Breivik, T.; Thrane, P.S.; Murison, R.; Gjermo, P. Emotional stress effects on immunity, gingivitis and periodontitis. Eur. J. Oral Sci. 1996, 104, 327-334. [CrossRef]

7. Savage, A.; Eaton, K.A.; Moles, D.R.; Needleman, I. A systematic review of definitions of periodontitis and methods that have been used to identify this disease. J. Clin. Periodontol. 2009, 36, 458-467. [CrossRef]

8. Eke, P.I.; Dye, B.A.; Wei, L.; Slade, G.D.; Thornton-Evans, G.O.; Borgnakke, W.S.; Taylor, G.W.; Page, R.C.; Beck, J.D.; Genco, R.J. Update on Prevalence of Periodontitis in Adults in the United States: NHANES 2009 to 2012. J. Periodontol. 2015, 86, 611-622. [CrossRef] [PubMed]

9. Machado, V.; Botelho, J.; Amaral, A.; Proença, L.; Alves, R.; Rua, J.; Cavacas, M.A.; Delgado, A.S.; Mendes, J.J. Prevalence and extent of chronic periodontitis and its risk factors in a Portuguese subpopulation: A retrospective cross-sectional study and analysis of Clinical Attachment Loss. PeerJ 2018, 6, e5258. [CrossRef]

10. Sun, H.Y.; Jiang, H.; Du, M.Q.; Wang, X.; Feng, X.P.; Hu, D.Y.; Lin, H.C.; Wang, B.; Si, Y.; Wang, C.X.; et al. The Prevalence and Associated Factors of Periodontal Disease among 35 to 44-year-old Chinese Adults in the 4th National Oral Health Survey. Chin. J. Dent. Res. Off. J. Sci. Sect. Chin. Stomatol. Assoc. (CSA) 2018, 21, 241-247.

11. Pereira, L.J.; Gazolla, C.M.; Magalhães, I.B.; Dominguete, M.H.L.; Vilela, G.R.; Castelo, P.M.; Marques, L.S.; Van Der Bilt, A. Influence of periodontal treatment on objective measurement of masticatory performance. J. Oral Sci. 2012, 54, 151-157. [CrossRef] [PubMed]

12. Papapanou, P.N.; Sanz, M.; Buduneli, N.; Dietrich, T.; Feres, M.; Fine, D.H.; Flemmig, T.F.; Garcia, R.; Giannobile, W.V.; Graziani, F.; et al. Periodontitis: Consensus report of workgroup 2 of the 2017 World Workshop on the Classification of Periodontal and Peri-Implant Diseases and Conditions. J. Clin. Periodontol. 2018, 45, S162-S170. [CrossRef] [PubMed]

13. Chapple, I.L.; Bouchard, P.; Cagetti, M.G.; Campus, G.; Carra, M.-C.; Cocco, F.; Nibali, L.; Hujoel, P.; Laine, M.L.; Lingström, P.; et al. Interaction of lifestyle, behaviour or systemic diseases with dental caries and periodontal diseases: Consensus report of group 2 of the joint EFP/ORCA workshop on the boundaries between caries and periodontal diseases. J. Clin. Periodontol. 2017, 44, S39-S51. [CrossRef] [PubMed]

14. Thomas, B.; Prasad, B.R.; Kumari, N.S.; Radhakrishna, V.; Ramesh, A. A comparative evaluation of the micronutrient profile in the serum of diabetes mellitus Type II patients and healthy individuals with periodontitis. J. Indian Soc. Periodontol. 2019, 23, 12-20. [CrossRef] [PubMed]

15. Naqvi, A.; Hasturk, H.; Mu, L.; Phillips, R.; Davis, R.; Halem, S.; Campos, H.; Goodson, J.; Van Dyke, T.; Mukamal, K. Docosahexaenoic Acid and Periodontitis in Adults. J. Dent. Res. 2014, 93, 767-773. [CrossRef] [PubMed]

16. Woelber, J.P.; Bremer, K.; Vach, K.; König, D.; Hellwig, E.; Ratka-Krüger, P.; Al-Ahmad, A.; Tennert, C. An oral health optimized diet can reduce gingival and periodontal inflammation in humans-A randomized controlled pilot study. BMC Oral Health 2016, 17, 28. [CrossRef]

17. Silva, V.D.O.; Pereira, L.J.; Murata, R.M. Oral microbe-host interactions: Influence of $\beta$-glucans on gene expression of inflammatory cytokines and metabolome profile. BMC Microbiol. 2017, 17, 1-9. [CrossRef]

18. Dodington, D.W.; Fritz, P.C.; Sullivan, P.J.; Ward, W.E. Higher Intakes of Fruits and Vegetables, $\beta$-Carotene, Vitamin C, $\alpha-$ Tocopherol, EPA, and DHA Are Positively Associated with Periodontal Healing after Nonsurgical Periodontal Therapy in Nonsmokers but Not in Smokers. J. Nutr. 2015, 145, 2512-2519. [CrossRef] [PubMed]

19. Kaur, G.; Kathariya, R.; Bansal, S.; Singh, A.; Shahakar, D. Dietary antioxidants and their indispensable role in periodontal health. J. Food Drug Anal. 2016, 24, 239-246. [CrossRef]

20. Varela-López, A.; Navarro-Hortal, M.D.; Giampieri, F.; Bullón, P.; Battino, M.; Quiles, J.L. Nutraceuticals in Periodontal Health: A Systematic Review on the Role of Vitamins in Periodontal Health Maintenance. Molecules 2018, 23, 1226. [CrossRef]

21. Lee, J.-H.; Shin, M.-S.; Kim, E.-J.; Ahn, Y.-B.; Kim, H.-D. The association of dietary vitamin C intake with periodontitis among Korean adults: Results from KNHANES IV. PLoS ONE 2017, 12, e0177074. [CrossRef]

22. Isola, G.; Polizzi, A.; Muraglie, S.; Leonardi, R.; Giudice, A.L. Assessment of Vitamin C and Antioxidant Profiles in Saliva and Serum in Patients with Periodontitis and Ischemic Heart Disease. Nutrients 2019, 11, 2956. [CrossRef] [PubMed]

23. Collins, C.; Araujo, J.; Barbosa, J. Decentralising the health sector: Issues in Brazil. Heal. Policy 2000, 52, 113-127. [CrossRef]

24. Paim, J.; Travassos, C.; Almeida, C.; Bahia, L.; Macinko, J. The Brazilian health system: History, advances, and challenges. Lancet 2011, 377, 1778-1797. [CrossRef] 
25. Bastos, J.L.; Boing, A.F.; Peres, K.G.; Antunes, J.L.F.; Peres, M.A. Periodontal outcomes and social, racial and gender inequalities in Brazil: A systematic review of the literature between 1999 and 2008. Cad. de Saúde Pública 2011, 27, s141-s153. [CrossRef] [PubMed]

26. Health Ministry. Secretariat of Primary Health Care (SAPS). Family Health Strategy (FHS). 2019. Available online: https: / / aps.saude.gov.br/ape/esf/ (accessed on 12 March 2021).

27. Mullachery, P.; Silver, D.; Macinko, J. Changes in health care inequity in Brazil between 2008 and 2013. Int. J. Equity Health 2016, 15, 1-12. [CrossRef]

28. Health Ministry. Secretariat of Primary Health Care (SAPS). e-Gestor Primary Care-Space for information and access to Primary Care systems. 2017. Available online: https:/ / egestorab.saude.gov.br/ (accessed on 12 March 2021).

29. Malta, D.C.; Santos, M.A.S.; Stopa, S.R.; Vieira, J.E.B.; Melo, E.A.; Dos Reis, A.A.C. A Cobertura da Estratégia de Saúde da Família (ESF) no Brasil, segundo a Pesquisa Nacional de Saúde, 2013. Ciência Saúde Coletiva 2016, 21, 327-338. [CrossRef] [PubMed]

30. Morosini, M.V.; Fonseca, A.F. Community workers in Primary Health Care in Brazil: An inventory of achievements and challenges. Saúde Debate São Paulo 2018, 42, 261-274. [CrossRef]

31. Haas, A.; Wagner, M.C.; Oppermann, R.V.; Rösing, C.K.; Albandar, J.M.; Susin, C. Risk factors for the progression of periodontal attachment loss: A 5-year population-based study in South Brazil. J. Clin. Periodontol. 2014, 41, 215-223. [CrossRef]

32. Bernal, R.T.I.; Iser, B.P.M.; Malta, D.C.; Claro, R.M. Sistema de Vigilância de Fatores de Risco e Proteção para Doenças Crônicas por Inquérito Telefônico (Vigitel): Mudança na metodologia de ponderação. Epidemiol. Serv. Saude Rev. Sist. Unico Saude Bras. 2017, 26, 701-712. [CrossRef]

33. Fisberg, R.M.; Colucci, A.C.A.; Morimoto, J.M.; Marchioni, D.M.L. Questionário de freqüência alimentar para adultos com base em estudo populacional. Rev. Saúde Pública 2008, 42, 550-554. [CrossRef]

34. Health Ministry. Orientações Para Coleta e Análise de Dados Antropométricos em Serviços de Saúde-Norma Técnica de Sistema de Vigilância Alimentar e Nutricional-SISVAN. 2011. Available online: https:/ / sisaps.saude.gov.br/sisvan/ (accessed on 12 March 2021).

35. Landry, R.; Jean, M. Periodontal Screening and Recording (PSR) Index: Precursors, utility and limitations in a clinical setting. Int Dent. J. 2002, 52, 35-40. [CrossRef] [PubMed]

36. World Health Organization. The World Health Report 1995-Bridging the Gaps. 1995. Available online: https://www.who.int/ whr/1995/en/ (accessed on 14 December 2020).

37. World Health Organization. Obesity: Preventing and Managing the Global Epidemic. WHO Expert Consultation; Technical Report Series No. 894; WHO: Geneva, Switzerland, 2000.

38. Polk, D.E.; Wang, X.; Feingold, E.; Shaffer, J.R.; Weeks, D.E.; Weyant, R.J.; Crout, R.J.; McNeil, D.W.; Marazita, M.L. Effects of Smoking and Genotype on the PSR Index of Periodontal Disease in Adults Aged 18-49. Int. J. Environ. Res. Public Health 2012, 9, 2839-2850. [CrossRef] [PubMed]

39. Padovani, R.M.; Amaya-Farfán, J.; Colugnati, F.A.B.; Domene, S.M. Álvares Dietary reference intakes: Aplicabilidade das tabelas em estudos nutricionais. Rev. Nutr. 2006, 19, 741-760. [CrossRef]

40. Maggini, S.; Pierre, A.; Calder, P.C. Immune Function and Micronutrient Requirements Change over the Life Course. Nutrients 2018, 10, 1531. [CrossRef] [PubMed]

41. Sundaram, G.; Ramakrishnan, T.; Parthasarathy, H.; Moses, J.; Lalitha, T. Evaluation of micronutrient (Zinc, Magnesium, and Copper) levels in serum and glycemic status after nonsurgical periodontal therapy in type 2 diabetic patients with chronic periodontitis. Contemp. Clin. Dent. 2017, 8, 26-32. [CrossRef]

42. Chasapis, C.T.; Loutsidou, A.C.; Spiliopoulou, C.A.; Stefanidou, M.E. Zinc and human health: An update. Arch. Toxicol. 2012, 86, 521-534. [CrossRef]

43. Rink, L.; Gabriel, P. Zinc and the immune system. Proc. Nutr. Soc. 2000, 59, 541-552. [CrossRef]

44. Beyersmann, D. Homeostasis and Cellular Functions of Zinc. Mater. Werkst. 2002, 33, 764-769. [CrossRef]

45. Debjit Bhowmik, C.; Kumar, K.P.S. A potential medicinal importance of zinc in human health and chronic disease. Int. J. Pharm. Biomed. Sci. 2010, 1, 5-11.

46. Tapiero, H.; Tew, K.D. Trace elements in human physiology and pathology: Zinc and metallothioneins. Biomed. Pharmacother. 2003, 57, 399-411. [CrossRef]

47. Shan, Z.; Bao, W.; Zhang, Y.; Rong, Y.; Wang, X.; Jin, Y.; Song, Y.; Yao, P.; Sun, C.; Hu, F.B.; et al. Interactions Between Zinc Transporter-8 Gene (SLC30A8) and Plasma Zinc Concentrations for Impaired Glucose Regulation and Type 2 Diabetes. Diabetes 2013, 63, 1796-1803. [CrossRef]

48. De Carvalho, G.B.; Brandão-Lima, P.N.; Maia, C.S.C.; Barbosa, K.B.F.; Pires, L.V. Zinc's role in the glycemic control of patients with type 2 diabetes: A systematic review. BioMetals 2017, 30, 151-162. [CrossRef] [PubMed]

49. Saharia, G.K.; Goswami, R.K. Evaluation of Serum Zinc Status and Glycated Hemoglobin of Type 2 Diabetes Mellitus Patients in a Tertiary Care Hospital of Assam. J. Lab. Physicians 2013, 5, 30-33. [CrossRef]

50. Sinha, S.; Sen, S. Status of zinc and magnesium levels in type 2 diabetes mellitus and its relationship with glycemic status. Int. J. Diabetes Dev. Ctries. 2014, 34, 220-223. [CrossRef]

51. Andrade, E.F.; Lima, A.R.V.; Nunes, I.E.; Orlando, D.R.; Gondim, P.N.; Zangeronimo, M.G.; Alves, F.H.F.; Pereira, L.J. Exercise and Beta-Glucan Consumption (Saccharomyces cerevisiae) Improve the Metabolic Profile and Reduce the Atherogenic Index in Type 2 Diabetic Rats (HFD/STZ). Nutrients 2016, 8, 792. [CrossRef] [PubMed] 
52. Silva, V.D.O.; Lobato, R.V.; Andrade, E.F.; De Macedo, C.G.; Napimoga, J.T.C.; Napimoga, M.H.; Messora, M.R.; Murata, R.M.; Pereira, L.J. $\beta$-Glucans (Saccharomyces cereviseae) Reduce Glucose Levels and Attenuate Alveolar Bone Loss in Diabetic Rats with Periodontal Disease. PLoS ONE 2015, 10, e0134742. [CrossRef]

53. Silva, V.D.O.; Lobato, R.V.; Andrade, E.F.; Orlando, D.R.; Borges, B.D.; Zangeronimo, M.G.; De Sousa, R.V.; Pereira, L.J. Effects of $\beta$-Glucans Ingestion on Alveolar Bone Loss, Intestinal Morphology, Systemic Inflammatory Profile, and Pancreatic $\beta$-Cell Function in Rats with Periodontitis and Diabetes. Nutrients 2017, 9, 1016. [CrossRef] [PubMed]

54. Lobato, R.V.; Silva, V.D.O.; Andrade, E.F.; Orlando, D.R.; Zangeronimo, M.G.; De Sousa, R.V.; Pereira, L.J. Metabolic effects of-glucans (Saccharomyces cerevisae) per os administration in rats with streptozotocin-induced diabetes. Nutr. Hosp. 2015, 32, 256-264.

55. Nielsen, S.J.; Trak-Fellermeier, M.A.; Joshipura, K.; Dye, B.A. Dietary Fiber Intake Is Inversely Associated with Periodontal Disease among US Adults. J. Nutr. 2016, 146, 2530-2536. [CrossRef]

56. Stier, H.; Ebbeskotte, V.; Gruenwald, J. Immune-modulatory effects of dietary Yeast Beta-1,3/1,6-D-glucan. Nutr. J. 2014, 13, 38. [CrossRef]

57. Buttriss, J.L.; Stokes, C.S. Dietary fibre and health: An overview. Nutr. Bull. 2008, 33, 186-200. [CrossRef]

58. Salvi, G.; Lang, N.P. The Effects of Non-Steroidal Anti-Inflammatory Drugs (Selective and Non-Selective) on the Treatment of Periodontal Diseases. Curr. Pharm. Des. 2005, 11, 1757-1769. [CrossRef]

59. Azzi, D.V.; Viafara, J.A.S.; Zangeronimo, M.G.; Lima, R.R.; Marques, L.S.; Pereira, L.J. n-3 Ingestion may modulate the severity of periodontal disease? Systematic review. Crit. Rev. Food Sci. Nutr. 2017, 58, 1937-1942. [CrossRef] [PubMed]

60. Serhan, C.N.; Hong, S.; Gronert, K.; Colgan, S.P.; Devchand, P.R.; Mirick, G.; Moussignac, R.-L. Resolvins. J. Exp. Med. 2002, 196, 1025-1037. [CrossRef] [PubMed]

61. Arita, M.; Bianchini, F.; Aliberti, J.; Sher, A.; Chiang, N.; Hong, S.; Yang, R.; Petasis, N.A.; Serhan, C.N. Stereochemical assignment, antiinflammatory properties, and receptor for the omega-3 lipid mediator resolvin E1. J. Exp. Med. 2005, 201, 713-722. [CrossRef]

62. Gyurko, R.; Van Dyke, T.E. The role of polyunsaturated $\omega-3$ fatty acid eicosapentaenoic acid-derived resolvin E1 (RvE1) in bone preservation. Crit. Rev. Immunol. 2014, 34, 347-357. [CrossRef]

63. Balta, M.G.; Loos, B.G.; Nicu, E.A. Emerging Concepts in the Resolution of Periodontal Inflammation: A Role for Resolvin E1. Front. Immunol. 2017, 8, 1682. [CrossRef] [PubMed]

64. Bao, M.; Zhang, K.; Wei, Y.; Hua, W.; Gao, Y.; Li, X.; Ye, L. Therapeutic potentials and modulatory mechanisms of fatty acids in bone. Cell Prolif. 2019, 53, e12735. [CrossRef] [PubMed]

65. Dos Santos, N.C.C.; Andere, N.M.R.B.; Araujo, C.F.; De Marco, A.C.; Kantarci, A.; Van Dyke, T.E.; Santamaria, M.P. Omega-3 PUFA and aspirin as adjuncts to periodontal debridement in patients with periodontitis and type 2 diabetes mellitus: Randomized clinical trial. J. Periodontol. 2020, 91, 1318-1327. [CrossRef]

66. Padayatty, S.J.; Katz, A.; Wang, Y.; Eck, P.; Kwon, O.; Lee, J.-H.; Chen, S.; Corpe, C.; Dutta, A.; Dutta, S.K.; et al. Vitamin C as an Antioxidant: Evaluation of Its Role in Disease Prevention. J. Am. Coll. Nutr. 2003, 22, 18-35. [CrossRef]

67. Dixon, D.; Hildebolt, C.F.; Miley, D.D.; Garcia, M.N.; Pilgram, T.K.; Couture, R.; Spearie, C.A.; Civitelli, R. Calcium and vitamin D use among adults in periodontal disease maintenance programmes. Br. Dent. J. 2009, 206, 627-631. [CrossRef]

68. Miley, D.D.; Garcia, M.N.; Hildebolt, C.F.; Shannon, W.D.; Couture, R.A.; Spearie, C.L.A.; Dixon, D.A.; Langenwalter, E.M.; Mueller, C.; Civitelli, R. Cross-Sectional Study of Vitamin D and Calcium Supplementation Effects on Chronic Periodontitis. J. Periodontol. 2009, 80, 1433-1439. [CrossRef]

69. Yamori, M.; Njelekela, M.; Mtabaji, J.; Yamori, Y.; Bessho, K. Hypertension, Periodontal Disease, and Potassium Intake in Nonsmoking, Nondrinker African Women on No Medication. Int. J. Hypertens. 2011, 2011, 695719. [CrossRef] [PubMed]

70. Ebersole, J.L.; Dawson, D.A.; Huja, P.E.; Pandruvada, S.; Basu, A.; Nguyen, L.; Zhang, Y.; Gonzalez, O.A. Age and Periodontal Health-Immunological View. Curr. Oral Health Rep. 2018, 5, 229-241. [CrossRef] [PubMed]

71. Hegde, S.; Chatterjee, E.; Rajesh, K.S.; Kumar, M.S.A. Obesity and its association with chronic periodontitis: A cross-sectional study. J. Educ. Health Promot. 2019, 8, 222. [PubMed]

72. Fentoğlu, Ö.; Öz, G.; Taşdelen, P.; Uskun, E.; Aykaç, Y.; Bozkurt, F.Y. Periodontal Status in Subjects with Hyperlipidemia. J. Periodontol. 2009, 80, 267-273. [CrossRef]

73. Dutt, P.; Chaudhary, S.; Kumar, P. Oral Health and menopause: A comprehensive review on current knowledge and associated dental management. Ann. Med Health Sci. Res. 2013, 3, 320-323. [CrossRef] [PubMed]

74. Buencamino, M.C.A.; Palomo, L.; Thacker, H.L. How menopause affects oral health, and what we can do about it. Clevel. Clin. J. Med. 2009, 76, 467-475. [CrossRef] [PubMed]

75. Ayed, M.S.; Alsharif, A.F.; Divakar, D.D.; Jhugroo, C.; Alosaimi, B.; Mustafa, M. Evaluating the possible association between systemic osteoporosis and periodontal disease progression in postmenopausal women. Disease-A-Month 2019, 65, 193-215. [CrossRef] [PubMed]

76. Nagarajan, R.; Miller, C.S.; Dawson, D.; Al-Sabbagh, M.; Ebersole, J.L. Cross-talk between clinical and host-response parameters of periodontitis in smokers. J. Periodontal Res. 2016, 52, 342-352. [CrossRef]

77. Ebersole, J.L.; Al-Sabbagh, M.; Gonzalez, O.A.; Dawson, D.R. Ageing effects on humoral immune responses in chronic periodontitis. J. Clin. Periodontol. 2018, 45, 680-692. [CrossRef] [PubMed] 
78. Chang, C.-H.; Han, M.-L.; Teng, N.-C.; Lee, C.-Y.; Huang, W.-T.; Lin, C.-T.; Huang, Y.-K. Cigarette Smoking Aggravates the Activity of Periodontal Disease by Disrupting Redox Homeostasis-An Observational Study. Sci. Rep. 2018, 8, 11055. [CrossRef] [PubMed]

79. Sanz, M.; Teughels, W.; on behalf of Group A of the European Workshop on Periodontology. Innovations in non-surgical periodontal therapy: Consensus Report of the Sixth European Workshop on Periodontology. J. Clin. Periodontol. 2008, 35, 3-7. [CrossRef]

80. Lee, J.; Taneja, V.; Vassallo, R. Cigarette Smoking and Inflammation. J. Dent. Res. 2011, 91, 142-149. [CrossRef]

81. Lee, M.; Choi, Y.-H.; Sagong, J.; Yu, S.; Kim, Y.; Lee, D.; Kim, S. The interactive association of smoking and drinking levels with presence of periodontitis in South Korean adults. BMC Oral Health 2016, 16, 1-9. [CrossRef]

82. Britton, A.; Ben-Shlomo, Y.; Benzeval, M.; Kuh, D.; Bell, S. Life course trajectories of alcohol consumption in the United Kingdom using longitudinal data from nine cohort studies. BMC Med. 2015, 13, 1-9. [CrossRef]

83. Giacosa, A.; Adam-Blondon, A.F.; Baer-Sinnott, S.; Barale, R.; Bavaresco, L.; Di Gaspero, G.; Dugo, L.; Ellison, R.C.; Gerbi, V.; Gifford, D.; et al. Alcohol and wine in relation to cancer and other diseases. Eur. J. Cancer Prev. 2012, 21, 103-108. [CrossRef]

84. Szabo, G. Consequences of alcohol consumption on host defence. Alcohol 1999, 34, 830-841. [CrossRef]

85. Wang, J.; Lv, J.; Wang, W.; Jiang, X. Alcohol consumption and risk of periodontitis: A meta-analysis. J. Clin. Periodontol. 2016, 43, 572-583. [CrossRef]

86. Ministério da Saúde. (SAPS) Sistema de Informação e Gestão da Atenção Básica (e-Gestor). Available online: https:/ / egestorab. saude.gov.br/index.xhtml (accessed on 2 August 2020).

87. Pinto, L.F.; Giovanella, L. Do Programa à Estratégia Saúde da Família: Expansão do acesso e redução das internações por condições sensíveis à atenção básica (ICSAB). Ciência Saúde Coletiva 2018, 23, 1903-1914. [CrossRef]

88. Cabral, J.F.; Da Silva, A.M.C.; Mattos, I.E.; Neves, Á.D.Q.; Luz, L.L.; Ferreira, D.B.; Santiago, L.M.; Carmo, C.N.D. Vulnerabilidade e fatores associados em idosos atendidos pela Estratégia Saúde da Família. Ciência Saúde Coletiva 2019, 24, 3227-3236. [CrossRef]

89. Darmon, N.; Drewnowski, A. Contribution of food prices and diet cost to socioeconomic disparities in diet quality and health: A systematic review and analysis. Nutr. Rev. 2015, 73, 643-660. [CrossRef]

90. Verly, E.; Darmon, N.; Sichieri, R.; Sarti, F.M. Reaching culturally acceptable and adequate diets at the lowest cost increment according to income level in Brazilian households. PLOS ONE 2020, 15, e229439. [CrossRef] [PubMed]

91. Macinko, J.; De Andrade, F.B.; Junior, P.R.B.D.S.; Lima-Costa, M.F.; De Souza, P.R.B. Primary care and healthcare utilization among older Brazilians (ELSI-Brazil). Rev. Saúde Pública 2018, 52, 6s. [CrossRef] [PubMed]

92. Navarro, M.F.D.L.; Modena, K.C.D.S.; Bresciani, E. Social disparity and oral health. Braz. Oral Res. 2012, 26, 17-24. [CrossRef] [PubMed]

93. Nascimento, A.C.; Moysés, S.T.; Werneck, R.I.; Moysés, S.J. Oral health in the context of primary care in Brazil. Int. Dent. J. 2013, 63, 237-243. [CrossRef] 